\title{
Employment Dilemma and Solutions for the General College Graduate in China
}

\author{
Zhihong Li* \\ Business School \\ Jianghan University \\ Wuhan, China 430056
}

\begin{abstract}
The employment issue concerns the improvement of people's life, the stabilization of the society and the sustainable development of the economy and so on. Due to the various reasons such as employment perspectives, expansion of the college enrollment and paroxysmal healthy crisis,etc, the current employment situation of the general college graduate becomes more and more serious. Where to find solutions to this problem? The paper first analyzes the actual situation of the general college graduate's employment, then expounds the existent concerned employment problems, and finally puts forward the relative solutions.
\end{abstract}

Keywords-employment; dilemma; solution; general college graduates

\section{INTRODUCTION}

The time of graduation 2020 is approaching. This year, the college graduate is foreseen to get to 8740 thousand in China. With the returned people graduated from the oversea and those who have graduated in the past years and are unemployed, nearly more than 10000 thousand persons are competing for the job. What's worse, the 2019 Corona-virus have gravely affected the economy and leads to a serious reduction of the job position. The employment situation is remarkably bad not only for China but also for the whole world. From the Central Government to the relative local department to the individual, all are pondering this issue and trying to find out a suitable way.

\section{ACTUAL SITUATION OF THE EMPLOYMENT OF THE COLlege Graduate}

According to the Report on the Analysis of the Industrial Competitive Situation and Investment Earning about the Educational Information Construction and IT Application in China from 2020 to 2026, about 8740 thousand people will graduate from the general higher educational institute in 2020 with an increase of 400 thousand compared with the past year $^{[1]}$. Ten years ago, only 6000 thousand were graduated from the general college.

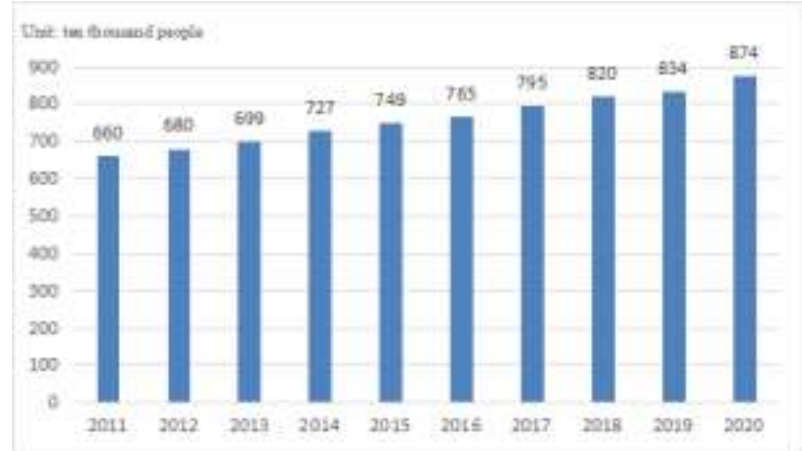

Fig. 1. Comparison of the College Graduate in Recent Ten Years

In recent years, China has achieved a great achievement and solved the people's food and clothing on the whole. But as the economy slows down so as to deal with the deep structural contradiction like industrial structure and environmental protection, etc, while the people looking for the job are fast rising, the employment issue, particularly that of the general college graduate becomes more and more remarkable. Currently the economic increase rate can't match that of the employment population rise. In 2020, the 2019 corona-virus is attacking the economy both at home and abroad much gravely than ever before. Many enterprises are going to the bankrupt and the unemployment is dramatically rising. The employment of the general college graduate is made worse, although the Chinese governments at all levels are formulating the correspondent policy to stimulate the economy and to support the employment.

\section{EMPLOYMENT PROBLEMS EXISTING OF THE GENERAL COLLEGE GRADUATE IN CHINA}

The employment problems ${ }^{[2]}$ mainly come from two aspects: endogenous and exogenous. In the endogenous aspect, the general college graduate expects too much in choosing the job.

First, most of them hope to work in the big city or in the open coastal city with better working conditions and relatively developed economy. Then, they have a higher need to the pay. It seems that most people don't recognize that the current employment situation is serious. Based on the Synthetic Investigation Report on the Best Employer of the 16th College Student in China from www.58.com, the expected average pay by the general college student 8.431 yuan per month. All these 
phenomena can't keep away from the insufficiency of their practical experience, stereotyped view of the employment and lack of the understanding to the society.

In the exogenous aspect, due to the expansion of the enrollment from the higher educational institute, the students graduated from the general college have greatly increased in recent ten years. Also, the modern service sector like productive logistics, consultation and $R \& D$,etc, which is able to absorb a large quantity of the labor forces with higher quality, lags behind ${ }^{[3]}$.

Then, as an essential component of the economy in China, the medium small enterprise plays a quite important role in the economic development. According to the relative statistics ${ }^{[4]}$, the medium small enterprise has contributed over $50 \%$ of the tax revenue, over $60 \%$ of GDP, over $70 \%$ of the technological innovation, over $80 \%$ of the urban labor force employment and over $90 \%$ of the enterprise number. The medium small enterprise is an indispensable foundation to set up the modern economic system and promote the economic development quality. It has an function unable to be replaced in improving people's life and expanding employment. However, the medium small enterprise has a limited demand of the people with higher quality because of its lack of the independent technology or brand. Even though some of them need the professional skilled personnel, they may meet much difficulty in hiring them for the sake of the lack of the competition in pay, treatment, career and working conditions ${ }^{[5]}$.

Next, the adaptation of the people's educational model needs to be raised as soon as possible. The fast evolution of the technology in information, network, new materials, new energy,etc drives the quick change in production, communication and life,etc. The traditional teaching system in the professional configuration, teaching content and style is being out of line with the market demand and employment situation $^{[6]}$. It is imperative to reform our educational system from enrollment to training in the correspondent institutions, professional components, teaching content and form and so on.

Finally, the disequilibrium development of the economy in different regions leads to a great contrast in clustering the skilled personnel. In the relative economic developed regions, the general college graduates strive to flow there and causes a surplus while in the less developed places such as remote areas, medium small towns, and hardship positions, etc, they are unwilling to work there and even though they have worked there, they can't stay long. All these situations cause a strange phenomenon: on the one hand, a lot of positions are vacant; on the other hand, many college graduates can't find a job.

\section{SOLUTIONS OF THE EMPLOYMENT FOR THE GENERAL COLLEGE GRADUATES IN CHINA}

Generally speaking, the outlets for the general college graduate in China consist of various enterprises, civil servants, public institutions, starting an own business, furthering the individual education, joining the army or supporting education $\&$ agriculture. As a college graduate, it is quite essential to have a reasonable choice at the beginning of his or her career.
First, truly evaluate oneself in the ability, majors, interest and career orientation and adjust the expectations in choosing the job. Facing all kinds of the employment outlets, the college graduate should make a career development plan based on his or her major and interests and family conditions ${ }^{[7]}$. One principle is to be remembered: survival first. Whatever you do, to support yourself and your family comes the most important. The big cities or coastal regions, with their relatively high pay, are attractive and fit for some people, but may be unfit for you. Some jobs of higher pay in the other areas need you to sacrifice more either in the working time or in the working conditions. When you select the job, you ought to make a full consideration of all these factors before making decisions ${ }^{[8]}$.

Then, the government ought to encourage the development of the medium small enterprise in the innovation of products and business model by way of formulating the correspondent policy. In this way, the demand of the professional people like the general college graduate can be enlarged. After all, the medium small enterprises occupy over $90 \%$ of the entity number and can hold a great deal of the population with professional knowledge. Meanwhile, for the sake of sustainable development, the medium small enterprise should attract and retain a certain number of the professional people by raising the pay and strengthening its business perspective.

Next, objectively treat what you have learned at university and what the human resources market demands ${ }^{[9]}$. In the current educational system in China, the educational reform always lag behind the need change of the skilled personnel in the human resources market. Originally, our higher education is not so closely connected with the real demand in the society. And some university students have never gone into the reality before graduation. They know little of what the human resources market really wants. This situation leads to an alienation between supply and demand. Besides, the expansion of the higher education in the latest years has caused a grave competition. To all these phenomena, the college graduate should early be ready and make sufficient practice in the enterprise or other relative institutions while studying at university so as to change his or her point of view and foster reasonable expectations in choosing the job.

Finally, the college graduate should transform his or her employment concept and continuously consolidate his or her skills from various ways ${ }^{[10]}$, for example, going where you are needed though hardship exists in these positions or though the pay is not high. It is worthwhile to do this only if you can be well tempered in your competitive ability. When you have accumulated enough working experience, an ideal job may be waiting for you, because most enterprises always give preference to those who have had synthetic competency when hiring the general college graduate.

\section{CONCLUSION}

The solution to the employment problem needs conjoint efforts of the individual, the enterprise and the government. The individual should make an objective position in the labor forces market, the enterprise should strengthen its competition so as to attract and retain the people and the government ought to formulate the correspondent policy to encourage the 
enterprise to provide the job and to normalize the labor forces market so that the college graduate could find a job. Only in this way can the employment pressure be eased up.

\section{ACKNOWLEDGMENT}

The paper is funded by the Discipline Group of the Integrative Management Between Economy and Industry in the City Circle, by the Wuhan Studies Institute, Hubei, China (IWHS20172001), and by Research Center on the Development of the Manufacturing Industry of the Wuhan City Circle, China (wz201607).

\section{REFERENCES}

[1] Analysis on the Employment of the College Graduate 2019, the Number, Employment Situation of the College Graduate 2020 and the Perspective of the Employment from the College Graduate in China, http://www.chyxx.com/industry/202002/837558.html, Feb.26, 2020.

[2] Ruiguang Zhang. Study on the Employment Issue of the College Graduate and Tactics. Business Information, no.41,2011.
[3] Dingge Dong, Yanqiu Li, Xiaomei Guan. Analysis and Research of the Employment Difficulty of the College Graduate. Modern Educational Science: Study on the Higher Education, no.1, 2009, Pp43-46.

[4] https://www.sohu.com/a/277818722_793673, 2018-11-27 16:14.

[5] Huina Chen, Yang Ding. Research of the Employment Problem of the College Graduate Based on the Employment Quality. Agricultural Economy, Science and Technology, no.8, 2007.

[6] Lijun Jia, Yun Xu. Psychological analysis of the Employment Ability of the College Graduate. Nanjing Social Science, no.10,2006.

[7] Wei Wang. Study on the Employment Competency Feature of the College Graduate and Tactics to Raise it. Journal of the Shangxi University, Social Science Edition, no.5, 2010.

[8] Ping Zhang. Empirical Analysis of the Employment Competency of the College Graduate and Countermeasure Suggestions. Journal of Beijing City College, no.1, 2012.

[9] Kuiying Liu, Lina Qie, Chunping Huang. Research of the Employment Competency Components of the College Graduate and its Relationship with the Employment Satisfaction. Journal of Hebei Industrial University, no.6, 2010.

[10] Xiaoming Tu. Empirical Research of the Factors Affecting the Employment Satisfaction of the College Graduate. Higher Educational Exploration, no.2, 2007. 